\title{
Genetic Disorders in the Growth Hormone - Insulin-Like Growth Factor-I Axis
}

\author{
M.J.E. Walenkamp J.M. Wit \\ on behalf of the Leiden Growth Genetics Working Group ${ }^{1}$ \\ Department of Pediatrics, Leiden University Medical Center, Leiden, The Netherlands
}

\section{Key Words}

Growth hormone $\cdot$ IGF-I $\cdot$ IGF-I receptor $\cdot$ Short stature $\cdot$

Genetic defect $\cdot$ Small for gestational age

\begin{abstract}
In the last few years, our knowledge of genetically determined causes of short stature has greatly increased by reports of challenging patients, who offered the opportunity to study genes that play a role in growth. Since the first paper that showed the etiology of Laron syndrome [Godowski PJ, et al: Proc Natl Acad Sci USA 1989;86:8083-8087], many mutations in the growth hormone $(\mathrm{GH})$ receptor have been identified. Recently, new mutations or deletions have been found in several components of the $\mathrm{GH}$-insulin-like growth factor-I (IGF-I) axis: a homozygous mutation of the GH1 gene, resulting in a bio-inactive $\mathrm{GH}$; mutations in the STAT5b gene, which plays a major role in the $\mathrm{GH}$ signal transduction; a ho-
\end{abstract}

1 The other members of the Leiden Growth Genetics Working Group are:

S.G. Kant ${ }^{\mathrm{a}}$, A.M. Pereira ${ }^{\mathrm{b}}$, M. Karperien ${ }^{\mathrm{b}, \mathrm{c}}$, W. Oostdijk ${ }^{\mathrm{c}}$, H.A. van Duyvenvoorde $^{\mathrm{b}, \mathrm{c}}$, M. Losekoot ${ }^{\mathrm{a}}$, M.H. Breuning ${ }^{\mathrm{a}}$, J.A. Romijn ${ }^{\mathrm{b}}$

${ }^{\mathrm{a}}$ Center for Human and Clinical Genetics, ${ }^{\mathrm{b}}$ Department of Endocrinology and Metabolism, and ${ }^{c}$ Department of Pediatrics, Leiden University Medical Center, Leiden, The Netherlands

\section{KARGER}

Fax +41613061234 E-Mail karger@karger.ch www.karger.com
(C) 2006 S. Karger AG, Basel

0301-0163/06/0665-0221\$23.50/0

Accessible online at:

www.karger.com/hre mozygous missense mutation in the IGF-I gene; heterozygous mutations in the IGF-I receptor gene and a homozygous deletion of the acid-labile subunit gene. In this mini review, we describe the clinical and biochemical features of these genetic defects. Genetic analysis has become essential in the diagnostic workup of a patient with short stature. However, regarding the time consuming nature of molecular analysis, it is important to carefully select the patient for specific genetic evaluation. To help in this selection process, we developed flowcharts, based on the recently described patients, that can be used as guidelines in the diagnostic process of patients with severe short stature of unknown origin.

Copyright $\odot 2006$ S. Karger AG, Basel

\section{Introduction}

Body growth is regulated by many genes, of which only a few have been clarified. However, in the last years our knowledge of genetically determined causes of short stature has greatly increased and genetic analysis is becoming essential in the diagnosis of short stature.

A review article in this journal in 2003 described the most important genetically determined causes of short stature and the genes involved [2]. Only 2 years later im-

M.J.E. Walenkamp

Department of Pediatrics J6-S, Leiden University Medical Center

PO Box 9600

NL-2300 RC Leiden (The Netherlands)

Tel. +31 71526 2824, Fax +31 71524 8198, E-Mail m.walenkamp@lumc.nl 
portant papers were published presenting new diseases, caused by genetic defects in the growth hormone $(\mathrm{GH})-$ insulin-like growth factor-I (IGF-I) axis. In this review, we will give an overview of the clinical aspects and the biochemical parameters for these genetic defects in the GH-IGF-I axis and we present a flow chart for the diagnostic approach of these disorders.

We will focus on those children, whose height is more than 2.5 SDS below the mean of the population reference. The first discriminating step in the diagnostic process of short stature is the presence or absence of dysmorphic features or disproportionate stature. Hereditary causes of short stature in combination with dysmorphic or disproportionate features were reviewed by Kant et al. [2]. In summary, in case of dysmorphic features a chromosomal abnormality (numeric, structural, mosaic or uniparental disomy) is suspected and karyotyping is indicated. Dysmorphic features may be minor, as seen in patients with Silver-Russell syndrome, who have in $10 \%$ of the cases uniparental disomy of chromosome 7. One can consider to look for Noonan syndrome, Prader Willi syndrome of 22q11 deletion in patients with short stature and subtle dysmorphic features.

Disproportionate short stature is the result of skeletal dysplasia, a category of disorders affecting in most cases the epiphysis, metaphysis or diaphysis of the long bones, with specific radiological characteristics. The genetic basis of these disorders is emerging, as many skeletal dysplasia gene loci have been identified. More than half of all patients with skeletal dysplasias have a mutation at COL2A1 or FGFR3. Mutations in the SHOX gene are even more frequent, but do not always present with skeletal abnormalities. $2-3 \%$ of the children with idiopathic short stature have a SHOX deletion or mutation [3]. It is particularly worthwhile to look for a SHOX deletion or mutation because treating these children with GH results in a similar catch-up growth as seen in girls with Turner syndrome treated with GH. Recently, deletions in the pseudoautosomal region downstream the SHOX gene were identified in patients with Leri Weill dyschondrosteosis [4]. Phenotypically these patients were indistinguishable from patients with SHOX deletion.

The child with proportionate short stature should be screened for organic, systemic and endocrine disorders. In children born small for gestation age (SGA) and a small head circumference chromosome disorders, congenital infections or exposure to toxins should be considered. After excluding organic and systemic diseases IGFI and IGFBP-3 measurements serve to focus on disturbances in the GH-IGF-I axis. As further diagnostic procedures heavily depend on IGF-I and IGFBP-3 concentrations, we would like to stress the importance of a reliable IGF-I and IGFBP-3 assay.

\section{GH-IGF-I Axis}

The GH-IGF-I axis plays a key role in regulating somatic growth. Genetic defects in one of the components (pituitary GH secretion, GH receptor (GHR), post-receptor signaling and IGF-I) of this axis usually result in proportionate growth retardation. In the last years, several patients with new genetic defects in the GH-IGF-I axis have been identified. We will summarize the genetic, biochemical and clinical aspects of these new findings (table 1).

\section{Pituitary GH Secretion}

Classical GH deficiency can be the result of a mutation in the GH releasing hormone receptor (GHRH-R) gene [5], a genetic defect in one of the genes playing a role in the ontogenesis of the $\mathrm{GH}$ producing cells in the anterior pituitary (POU1F1, PROP1, HESX1, LHX3, LHX4, etc.) [6] or a mutation or deletion of the GH1 gene [6]. Dysfunctional $\mathrm{GH}$ variants, caused by heterozygous missense mutations in the GH1 gene, have been described by Takahashi et al. [7]. Recently, the first homozygous missense mutation in the GH1 gene (GH-C53S) has been described [8]. This mutation leads to the absence of the disulfide bridge Cys-53 to Cys-165, resulting in reduced GHR binding and signaling. These genetic defects are comparatively rare causes of short stature.

Recent studies demonstrate high diversity in the proximal promoter region of the GH1 gene, resulting in some haplotypes that are associated with a reduced level of gene expression, while other haplotypes were associated with increased expression [9]. One can speculate that a haplotype, associated with reduced expression of GH, results in a condition with low spontaneous GH secretion and thus low levels of IGF-I, while stimulated GH secretion may be normal.

\section{Growth Hormone Receptor and GH Signaling}

The biological effects of GH can only be reached in the presence of a normal functioning GHR, and an intact post-receptor signaling pathway. Deletions and mutations in the extracellular domain of the GHR gene result in classical GH insensitivity (Laron syndrome). More recently, mutations in the transmembrane and intracellular domain of the receptor were identified, resulting in $\mathrm{GH}$ 
Table 1. Clinical and biochemical features of genetic defects in the GH-IGF-I axis

\begin{tabular}{|c|c|c|c|c|c|c|c|c|}
\hline & $\begin{array}{l}\text { Inactive } \\
\text { GH promoter }\end{array}$ & $\begin{array}{l}\text { GHR } \\
\text { defect }\end{array}$ & $\begin{array}{l}\text { Homozygous } \\
\text { STAT5B } \\
\text { defect }\end{array}$ & $\begin{array}{l}\text { ALS } \\
\text { defect }\end{array}$ & $\begin{array}{l}\text { IGF-I } \\
\text { deletion }\end{array}$ & $\begin{array}{l}\text { IGF-I } \\
\text { missense } \\
\text { mutation }\end{array}$ & $\begin{array}{l}\text { Heterozygous } \\
\text { IGF1R mutation }\end{array}$ & $\begin{array}{l}\text { Homozygous } \\
\text { GH1 gene } \\
\text { mutation }\end{array}$ \\
\hline \multicolumn{9}{|l|}{ History } \\
\hline Birth weight & $\mathrm{LN}$ & $\mathrm{LN}$ & $\mathrm{LN}$ & $\Downarrow$ & $\Downarrow$ & $\Downarrow$ & $\Downarrow$ & $\mathrm{N}$ \\
\hline Birth length & $\mathrm{LN}$ & $\Downarrow$ or LN & LN & $\Downarrow$ & $\Downarrow$ & $\Downarrow$ & $\Downarrow$ & LN \\
\hline Birth head circumference & $\mathrm{LN}$ & $\mathrm{LN}$ & $\mathrm{LN}$ & $?$ & $\Downarrow$ & $\Downarrow$ & $\Downarrow$ & $?$ \\
\hline Parental height & $\mathrm{N}$ & $\mathrm{N}$ & $\mathrm{N}$ & $?$ & $\mathrm{LN}$ & $\mathrm{LN}$ & $\begin{array}{l}1 \text { small parent } \\
\text { or both } \mathrm{N}\end{array}$ & $\mathrm{N}$ \\
\hline Appetite as infant & $\mathrm{N}$ & $\mathrm{N}$ & $\Downarrow$ or $\mathrm{N}$ & $\mathrm{N}$ & $\mathrm{N}$ & $\mathrm{N}$ & $\Downarrow$ & $\mathrm{N}$ \\
\hline Milestones & $\mathrm{N}$ & $\mathrm{N}$ & $\mathrm{N}$ & $\mathrm{N}$ & $\Downarrow$ & $\Downarrow$ & $\mathrm{N}$ or $\Downarrow$ & $\mathrm{N}$ \\
\hline Psychomotor development & $\mathrm{N}$ & $\mathrm{N}$ & $\mathrm{N}$ & $\mathrm{N}$ & $\Downarrow$ & $\Downarrow$ & $\mathrm{N}$ or $\Downarrow$ & $\mathrm{N}$ \\
\hline Immunodeficiency & - & - & + or - & - & - & - & - & - \\
\hline \multicolumn{9}{|l|}{ Physical exam } \\
\hline Height & $\Downarrow$ & $\Downarrow$ & $\Downarrow$ & $-2 \mathrm{SD}$ & $\Downarrow$ & $\Downarrow$ & $\Downarrow$ & $-3.6 \mathrm{SD}$ \\
\hline Weight for height & $\mathrm{N}$ & $\mathrm{N}$ & $?$ & $\mathrm{~N}$ & $\Downarrow$ & $\Downarrow$ & $\Downarrow$ & ? \\
\hline Head circumference & $N$ or $\Downarrow$ & Nor $\Downarrow$ & $?$ & LN & $\Downarrow$ & $\Downarrow$ & $\Downarrow$ & ? \\
\hline Sitting height/height ratio & $\mathrm{N}$ & $\mathrm{N}$ & $\mathrm{N}$ & $\mathrm{N}$ & $\mathrm{N}$ & $\mathrm{N}$ & $\mathrm{N}$ & ? \\
\hline Other problems & & & $\begin{array}{l}\text { Lymphoid inte } \\
\text { pneumonia, } \\
\text { pulmonary fib } \\
\text { hemorrhagic } \mathrm{v}\end{array}$ & & Deafness & Deafness & & \\
\hline \multicolumn{9}{|l|}{ Biochemistry } \\
\hline GH secretion & $\begin{array}{l}\text { GH peak } \\
\Downarrow \text { or N, } \\
12 \text { h profile } \Downarrow\end{array}$ & $\Uparrow$ & $\Uparrow$ & $\mathrm{N}$ & $\Uparrow$ & $\Uparrow$ & $\Uparrow$ or $\mathrm{N}$ & $\Uparrow$ \\
\hline IGF-I & $\Downarrow$ & $\Downarrow$ & $\Downarrow$ & $\Downarrow$ & $\Downarrow$ & $\Uparrow$ & Nor $\pi$ & $\Downarrow$ \\
\hline IGF-II & $\Downarrow$ & $?$ & $\mathrm{~N}$ & $\Downarrow$ & $\mathrm{N}$ & $\mathrm{N}$ & $\mathrm{N}$ & $?$ \\
\hline IGFBP-3 & $\Downarrow$ & $\Downarrow$ & $\Downarrow$ & $\Downarrow \Downarrow$ & $\mathrm{N}$ & $\mathrm{N}$ & $\mathrm{N}$ & $\Downarrow$ \\
\hline Insulin & $\Downarrow$ & $\mathrm{N}$ & $\mathrm{N}$ & $\Uparrow$ & $\Uparrow$ & $\mathrm{N}$ & $?$ & ? \\
\hline ALS & $\Downarrow$ & ? & $\Downarrow$ & 0 & $\mathrm{~N}$ & $\mathrm{~N}$ & $\Uparrow$ & ? \\
\hline Prolactin & $\mathrm{N}$ & $\mathrm{N}$ & $\Uparrow$ & $\mathrm{N}$ & $\mathrm{N}$ & $\mathrm{N}$ & $\mathrm{N}$ & $\mathrm{N}$ \\
\hline \multicolumn{9}{|l|}{ Radiology } \\
\hline Skeletal age & $\Downarrow$ & $\Downarrow$ & $\Downarrow$ & $\Downarrow$ & $\Downarrow$ & $\Downarrow$ & $\Downarrow$ & $\Downarrow$ \\
\hline
\end{tabular}

insensitivity syndrome with normal or high levels of GH binding protein [10-12].

The first report of a specific molecular defect in the GH signal transduction was published by Kofoed et al. [13]. The authors described a patient with a homozygous missense mutation in the highly conserved $\mathrm{SH} 2$ domain of the STAT5b gene, which is essential for the GH signaling cascade and IGF-I transcription. At the moment of writing this review, several patients with homozygous mutations in the STAT5b gene have been described: a frame shift mutation [14, 15], a nonsense mutation [16], another frameshift mutation [17], and a splice site mutation [18]. All patients appear to show hyperprolactinemia; some of them have a serious immunodeficiency, while others show no such clinical symptoms.
Recently, a heterozygous mutation of the I $\mathrm{B}$ gene was

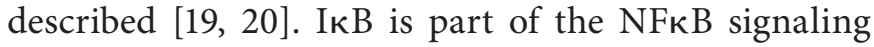
pathway, playing a major role in immune responses. Besides severe immune deficiency, this patient also had signs of partial GH insensitivity, suggesting that the NFкB pathway could play a role in the GH signal transduction.

\section{$I G F-I$}

One of the biological effects of GH is stimulating IGFI production, which is mainly taking place in the liver, but also in all other cells of the body. IGF-I has endocrine, paracrine and autocrine functions. IGF-I secretion is under control of many other factors than GH (e.g. nutrition). IGF-I, IGF-II and insulin are the most important 
regulators of prenatal growth. Postnatally, IGF-I remains important, while the role of IGF-II is still unclear. In 1996 , one patient with a homozygous deletion of exons 4 and 5 of the IGF-I gene was described. Phenotypically he showed intrauterine growth retardation, postnatal growth failure, microcephaly, mental retardation, sensorineural deafness and multiple dysmorphic features [21]. In 2003, a patient with intrauterine growth retardation, short stature, delayed psychomotor development and sensorineural deafness was described, with a homozygous mutation, changing the normal amino acid sequence of the E domain of the IGF-I precursor, resulting in low circulating levels of IGF-I [22]. In 2005, we described the first patient with a homozygous missense mutation of the IGF-I gene [23]. The phenotype of this 55-year-old patient was similar to that of the patient with an IGF-I deletion [21]. Family members with a heterozygous IGF-I mutation were shorter and had lower head circumferences than family members without the mutation. Recently, a boy was presented with a partial IGF-I deficiency due to a homozygous missense mutation of the IGF-I gene, resulting in pre- and postnatal growth retardation, microcephaly, mild developmental delay and normal hearing tests [24].

In the circulation IGF-I is bound to binding proteins (IGF-binding proteins, IGFBP's). These proteins exhibit specific characteristics in relation to delivery of IGF-I to different tissues. IGFBP-3 production is strongly dependent on GH. IGFBP-3 forms with IGF-I and acid-labile subunit (ALS) a ternary complex in the circulation. A homozygous deletion of the ALS gene, resulting in a 'circulating IGF-I deficiency', was described in 2004 [25]. This patient was not very short, but had a very delayed puberty. Later, a boy with a similar phenotype was reported [26].

IGF-I receptors (IGF1R) are widely spread through the body. Children with a deletion of the distal long-arm of chromosome 15, which includes the IGF1R gene, are short [27]. It was assumed that specific mutations/deletions of the IGF1R gene could result in growth retardation.

The first report on mutations in the IGF1R gene was published in 2003 by Abuzzahab et al. [28]: a compound heterozygous mutation of the IGF1R gene, resulting in reduced IGF-I binding and decreased receptor phosphorylation and a nonsense mutation in exon 2, resulting in reduced expression of IGF1R. Recently, a heterozygous mutation in the cleavage site of the proreceptor of IGF1R was reported in a 6-year-old Japanese girl and her mother [29]. We described a mother and daughter with a het- erozygous missense mutation in the intracellular part of the IGF1R [30]. A 13.6-year-old girl was presented with a heterozygous missense mutation in the highly conserved $\mathrm{N}$-terminal fibronectin type III domain of the IGF1R [31]. Recently, a new heterozygous missense mutation at the $\alpha$ subunit of the IGF-I receptor was described in a 4year-old girl with short stature (-3.6 SDS) and her mother [32].

\section{Proposal for a Diagnostic Flow Chart for Patients with Severe Short Stature of Unknown Origin}

Although we acknowledge that undoubtedly future studies will show additional cases of the genetic defects described above, as well as new genetic disorders, we think that developing a diagnostic algorithm might be helpful in the evaluation of severely short children. For this purpose, we developed some flowcharts, based on the recently described patients, in combination with theoretical considerations. The flowcharts can be used as guidelines in the diagnostic process of patients with idiopathic short stature. As our knowledge of genetic causes of short stature is increasing rapidly, these diagrams undoubtedly will be subject of adaptation in the coming years.

As main inclusion criterium for considering genetic evaluation, we choose a height SDS of $<-2.5$, assuming that more pathology is found with a lower height SDS. We believe that deviation of growth is not a valuable parameter, as in some of the earlier described cases growth is far below, but parallel to, the -2.5 SDS line. Similarly, target height cannot be used as criterium, because in some cases parents are short due to the same genetic defect (as in the cases of heterozygous IGF1R mutations).

Figure 1 shows the first diagnostic step in a child with a height $<-2.5$ SDS. Proportions should be measured and in case of disproportionate short stature a skeletal survey is performed and the child is referred to a clinical geneticist. Radiological abnormalities can point to a known skeletal dysplasia, requiring specific molecular analysis. If no or minimal radiological abnormalities are found, the SHOX and FGFR3 gene can be analyzed, as in some cases mild disproportionate short stature is the only clinical feature [33, 34].

Karyotyping should be carried out when dysmorphic features are found, but also in the absence of dysmorphic features karyotyping is usually carried out in all girls with unexplained short stature. Recently, it was argued that also in boys with short stature karyotyping should be considered, in order to diagnose a XY/X chromosom- 


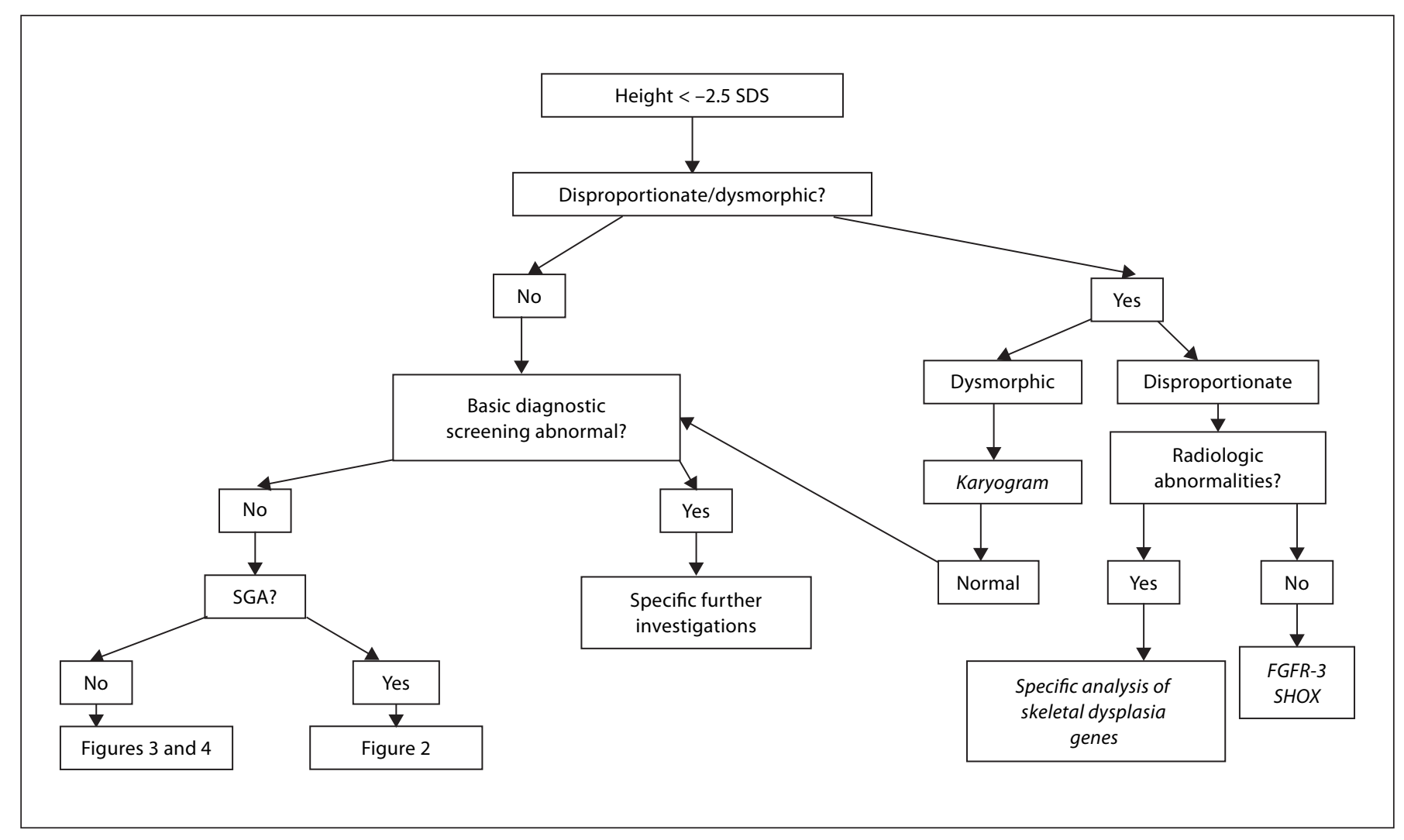

Fig. 1. Flow chart for the diagnostic approach of a child with short stature $(<-2.5$ SDS).

al pattern [35]. In the dysmorphic child with a normal karyogram a genetic defect of the GH-IGF-I axis is still possible: e.g. the patient with a deletion of the IGF-I gene [21] and the patients with IGF1R gene mutation showed dysmorphic features [28]. Obviously, if another cause for short stature is found by basic diagnostic screening, genetic analysis of the GH-IGF-I axis is not indicated.

The next criterium in a child with proportionate short stature is the presence or absence of being SGA, defined as a birth weight or length of $<-2$ SDS. In case of SGA, further investigations will be focused on genetic defects of IGF-I production or sensitivity. Indeed, children with classical GH deficiency or insensitivity are usually not born SGA. In case of SGA, one should look for mutations or deletions in the IGF-I or IGF1R gene or a IGF-I signal transduction defect. In children with a normal birth weight and length additional testing should be focused on disturbances in $\mathrm{GH}$ secretion, GH sensitivity or GH signaling.

In children with short stature, born SGA, measuring the head circumference is essential. IGF-I plays a key role in intrauterine growth and cerebral development and pre- natally IGF-I secretion is GH independent. Therefore, in SGA children with a small head circumference primary IGF-I deficiency or insensitivity should be considered (fig. 2). The IGF-I level will determine the differential diagnosis. Undetectable IGF-I levels will indicate a homozygous IGF-I deletion or nonsense mutation with absolutely no production of IGF-I. Theoretically, one can expect very low IGF-I levels in cases of a homozygous missense mutation in the IGF-I gene resulting in an abnormal IGF-I protein that can only be partially detected by the assay. IGF-I levels between -2 and 0 SDS could be the result of heterozygous mutations or deletions of IGF-I. It is conceivable that in the future polymorphisms in the promoter region of the IGF-I gene will be found that may explain the short stature in some of these cases. In case of a heterozygous mutation of IGF1R plasma IGF-I is usually elevated, but it can be low if the child is malnourished by extremely poor appetite [30]. In spite of these theoretical possibilities, at present, we do not advise further genetic analysis, at least with the current tools available, in patients with IGF-I levels in the lower normal range. The 


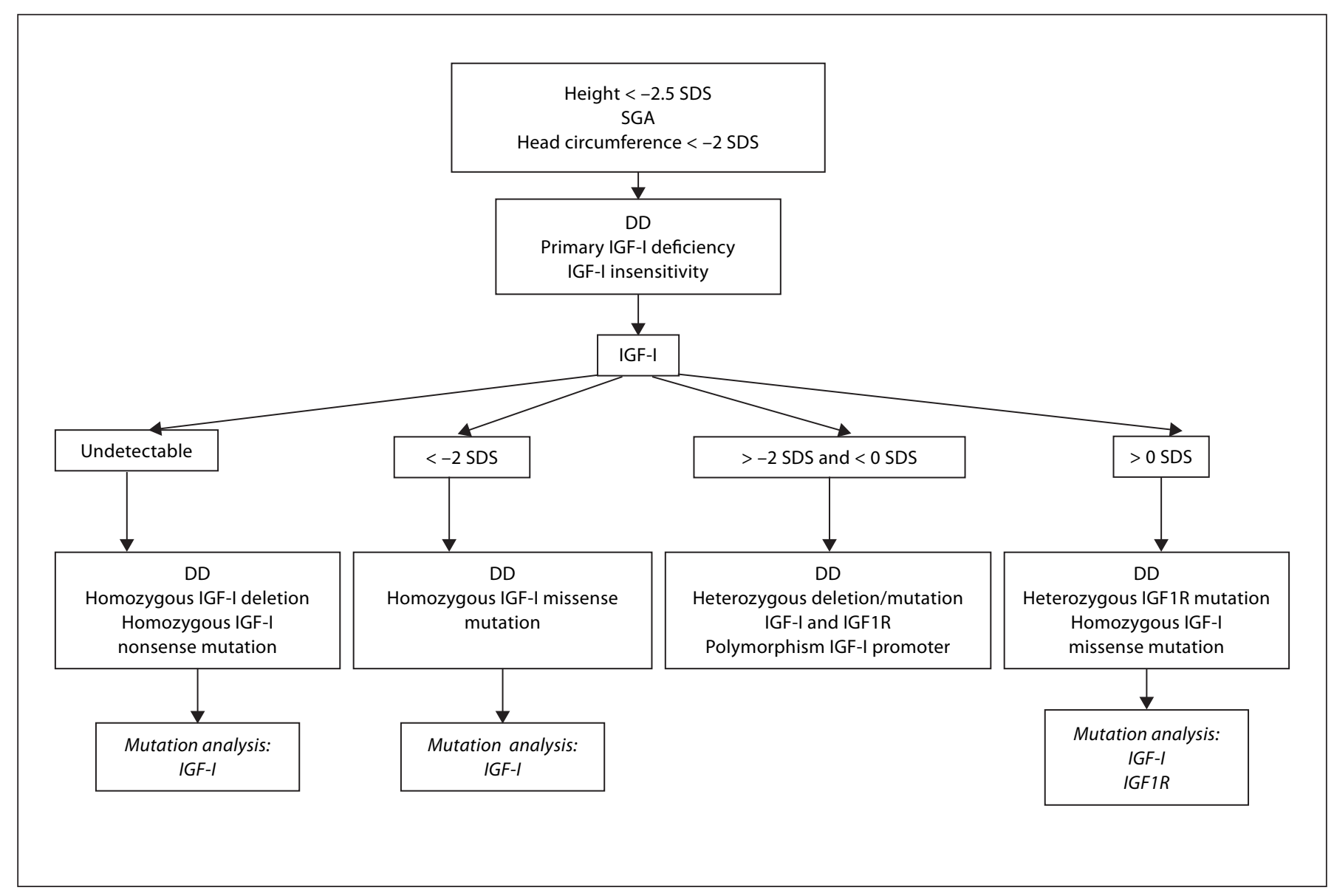

Fig. 2. Flow chart for the evaluation of a child with proportionate short stature, born SGA and a head circumference $<-2$ SDS.

differential diagnosis in patients with normal or high IGF-I levels consists of a homozygous IGF-I missense mutation, resulting in an abnormal IGF-I molecule, or a heterozygous IGF1R mutation with decreased or absent binding of IGF-I to the mutated receptor. In all these conditions, IGFBP-3 levels are within the normal range.

With a normal head circumference these genetic defects are less probable, but they cannot be completely ruled out. Heterozygous mutations or deletions of the IGF-I or IGF1R gene could present with short stature, SGA and a head circumference $>-2$ SDS. One may consider to perform in vitro experiments with fibroblasts of patients, that meet these criteria. Depending on the sensitivity of the fibroblasts to IGF-I, the IGF-I gene or the IGF1R gene can be sequenced.

We will now discuss the group of patients with short stature and a normal birth weight and length. The first diagnostic step in these patients is to determine the IGF-
I and IGFBP-3 levels. If the IGF-I level is below the normal range $(<-2$ SDS) the interpretation of the GH peak in a stimulation test determines the next step (fig. 3). An MRI of the pituitary-hypothalamus region should be performed to demonstrate or exclude anatomical defects.

GH deficiency is usually diagnosed if the GH peak is below $20 \mathrm{mU} / \mathrm{l}$ (equivalent to $6.6,7.7$ or $10 \mu \mathrm{g} / \mathrm{l}$, depending on the standard used) in two tests. Depending on the presence of other pituitary hormone deficiencies analysis of transcription factors as HESX-1, PROP-1, and Pit 1 is required. In special cases analysis of LHX3 or LHX4 can be considered. In case of isolated GH deficiency, we advise to analyze the GH and GHRH-R gene, but one can argue that these tests could be restricted to those children in whom a positive family history for short stature or extremely short stature is found.

A GH peak within the lower normal range (20$30 \mathrm{mU} / \mathrm{l}$ ) can be the result of a disturbance in the GH se- 


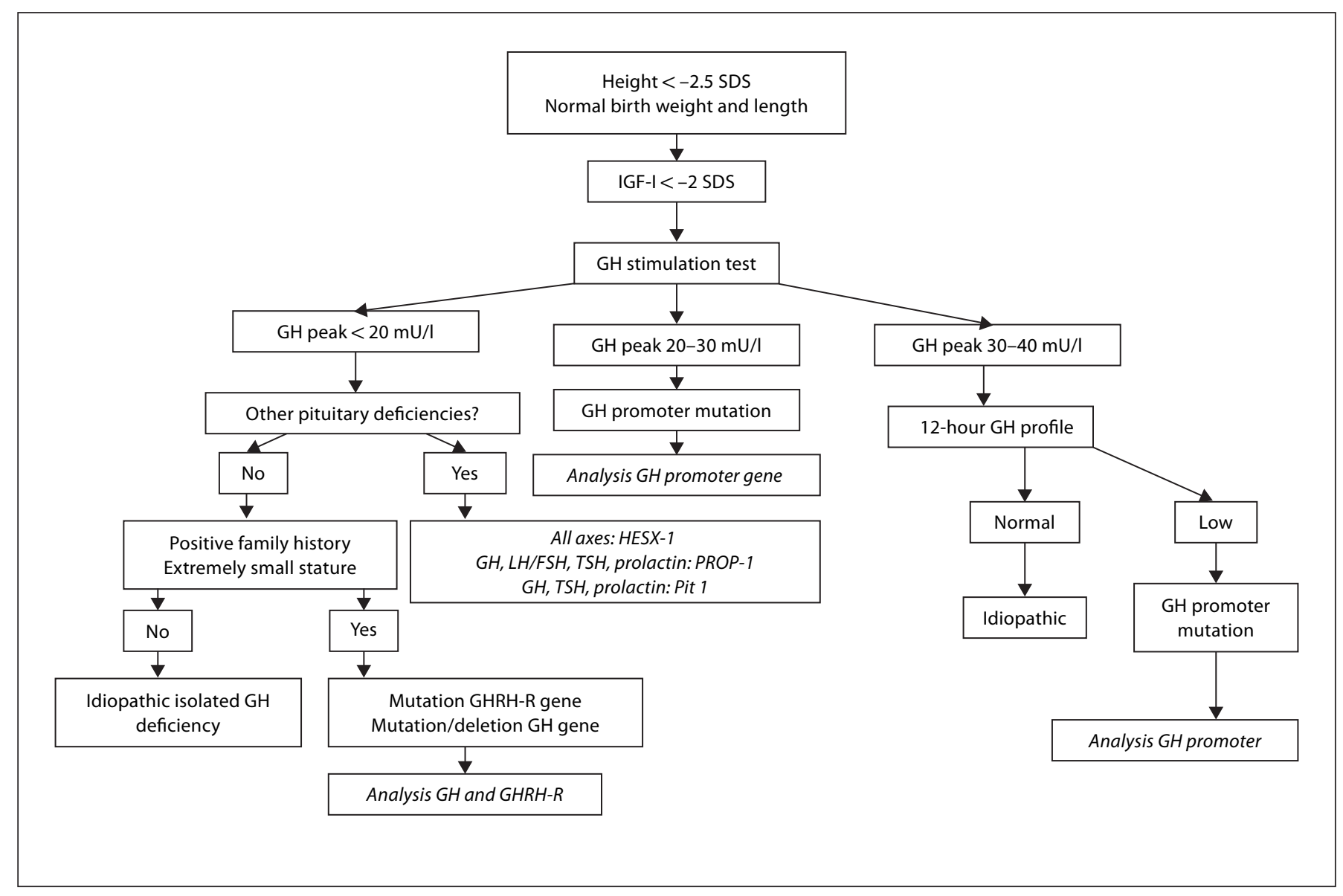

Fig. 3. Flow chart for the evaluation of a child with proportionate short stature, normal birth weight and length, low IGF-I levels (<-2 SDS) and a GH peak in a stimulation test $<40 \mathrm{mU} / \mathrm{l}$.

cretion and one can consider to analyze the GH promoter gene. In several countries, including the Netherlands, the combination of very low IGF-I and borderline GH peaks after stimulation, is sufficient indication for $\mathrm{GH}$ therapy. A low 12- or 24-hour profile, which has been termed 'neurosecretory dysfunction' by several investigators, could be used as criterium for analysis of the GH promoter gene.

A normal GH peak (30-40 mU/l) in combination with low IGF-I levels in patients with clinical features of GH deficiency and retarded skeletal maturation can be present. In these cases a low 12 - or 24 -hour GH profile could reflect a relatively inactive $\mathrm{GH}$ promoter haplotype. One should note, however, that in some cases with a GH signaling disorder very low IGF-I levels in the presence of normal GH peaks have been found.

The differential diagnosis of a low IGF-I in combination with a high stimulated $\mathrm{GH}$ secretion $(\mathrm{GH}$ peak
Table 2. IGF-I generation test

\begin{tabular}{lll}
\hline & Growth hormone dose & Biochemical evaluation \\
\hline Week 1 & $0.7 \mathrm{mg} / \mathrm{m}^{2} /$ day & $\begin{array}{l}\text { IGF-I and IGFBP-3 at } \\
\text { days } 0 \text { and } 8\end{array}$ \\
$\begin{array}{lll}\text { Wash out period (at least } 4 \text { weeks) } \\
\text { Week } 2\end{array}$ & $\begin{array}{l}\text { IGF-I and IGFBP-3 at } \\
\text { days } 0 \text { and } 8\end{array}$ \\
$\begin{array}{ll}\text { Wash out period (at least } 4 \text { weeks) } \\
\text { Week } 3\end{array} 2.8 \mathrm{mg} / \mathrm{m}^{2} /$ day & $\begin{array}{l}\text { IGF-I and IGFBP-3 at } \\
\text { days } 0 \text { and } 8\end{array}$
\end{tabular}

The response criterium is defined as an increase of IGF-I of at least 1 SD on day 8 . 


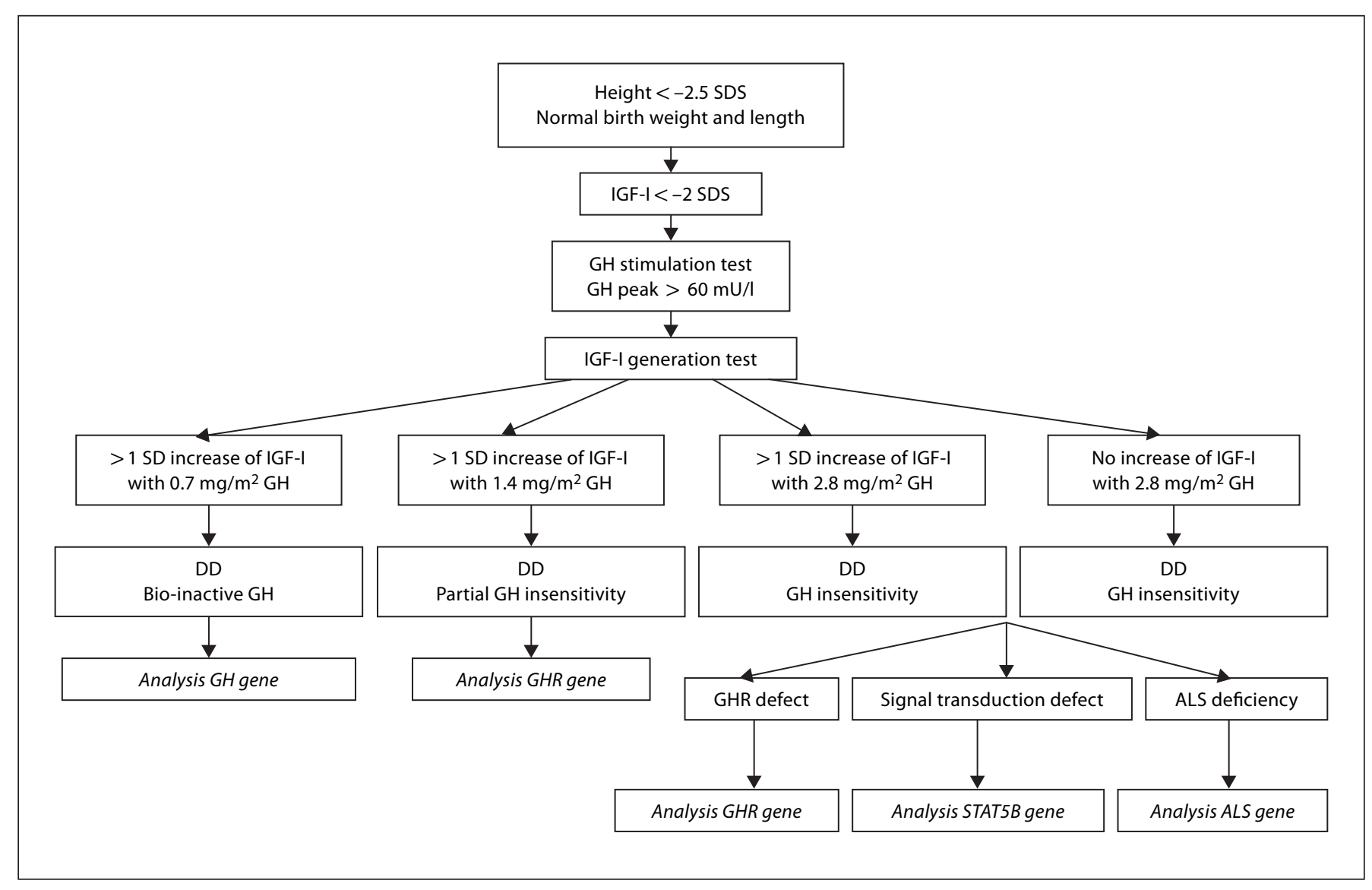

Fig. 4. Flow chart for the analysis of a child with proportionate short stature, normal birth weight and length, low IGF-I levels (<-2 SDS) and a GH peak in a stimulation test $>60 \mathrm{mU} / \mathrm{l}$.

$>60 \mathrm{mU} / \mathrm{l})$ consists of: bio-inactive GH, a GHR defect, a GH signal transduction defect (STAT5b mutation) or an ALS deficiency (fig. 4). The response of IGF-I to increasing doses of GH (the IGF-I generation test, described in table 2) will roughly distinguish the conditions characterized by an abnormal GH molecule from GH insensitivity states. We are aware that many different protocols for the IGF-I generation test have been described, and that the diagnostic value of all of them is still uncertain. Theoretically, in patients with a bio-inactive GH, IGF-I will reach normal levels with the lowest GH dose, while in patients with a GHR or post-receptor problem IGF-I will not increase or only on the highest GH dose.

Theoretically, an inactive $\mathrm{GH}$ promoter or partial GH insensitivity can result in low IGF-I levels with a normal GH peak in the stimulation test (40-60 mU/l). At his moment, however, we do not propose genetic analysis in these patients, as we think the time and money investment will not be balanced by the results.

\section{Conclusion}

In patients with short stature a systematic diagnostic approach may reveal the cause of the growth disorder. The medical history, including birth weight, length and head circumference, and physical examination, including body proportions, are necessary for the first differential diagnosis. Biochemical evaluation will point to a more specific diagnosis, which can be confirmed with molecular techniques. In this review, we discussed new genetic defects in the GH-IGF-I axis and proposed a practical flow chart for the diagnostic work-up.

The proposed diagnostic pathways will lead to maximum results when pediatric endocrinologists, adult endocrinologists, clinical geneticists and molecular biologists cooperate. An unusual presentation of a patient with a growth disorder should alert the clinician to look for new abnormalities in the GH-IGF-I axis or other genes involved in growth. 


\section{References}

1 Godowski PJ, Leung DW, Meacham LR, Galgani JP, Hellmiss R, Keret R, Rotwein PS, Parks JS, Laron Z, Wood WI: Characterization of the human growth hormone receptor gene and demonstration of a partial gene deletion in two patients with Laron-type dwarfism. Proc Natl Acad Sci USA 1989;86:80838087.

-2 Kant SG, Wit JM, Breuning MH: Genetic analysis of short stature. Horm Res 2003;60: 157-165.

$\checkmark 3$ Rappold GA, Fukami M, Niesler B, Schiller S, Zumkeller W, Bettendorf M, Heinrich U, Vlachopapadoupoulou E, Reinehr T, Onigata K, Ogata T: Deletions of the homeobox gene SHOX (short stature homeobox) are an important cause of growth failure in children with short stature. J Clin Endocrinol Metab 2002;87:1402-1406.

$\checkmark 4$ Benito-Sanz S, Thomas NS, Huber C, Gorbenko dB, Aza-Carmona M, Crolla JA, Maloney V, Rappold G, Argente J, Campos-Barros A, Cormier-Daire V, Heath KE: A novel class of Pseudoautosomal region 1 deletions downstream of SHOX is associated with Leri-Weill dyschondrosteosis. Am J Hum Genet 2005;77:533-544.

$\checkmark 5$ Wajnrajch MP, Gertner JM, Harbison MD, Chua SC Jr, Leibel RL: Nonsense mutation in the human growth hormone-releasing hormone receptor causes growth failure analogous to the little (lit) mouse. Nat Genet 1996; 12:88-90.

6 Mullis PE: Genetic control of growth. Eur J Endocrinol 2005;152:11-31.

-7 Takahashi Y, Kaji H, Okimura Y, Goji K, Abe $\mathrm{H}$, Chihara K: Brief report: short stature caused by a mutant growth hormone. N Engl J Med 1996;334:432-436.

$\checkmark 8$ Lewis MD, Horan M, Millar DS, Newsway V, Easter TE, Fryklund L, Gregory JW, Norin M, Del Valle CJ, Lopez-Siguero JP, Canete R, Lopez-Canti LF, Diaz-Torrado N, Espino R, Ulied A, Scanlon MF, Procter AM, Cooper DN: A novel dysfunctional growth hormone variant (Ile179Met) exhibits a decreased ability to activate the extracellular signalregulated kinase pathway. J Clin Endocrinol Metab 2004;89:1068-1075.

$\checkmark 9$ Horan M, Millar DS, Hedderich J, Lewis G, Newsway V, Mo N, Fryklund L, Procter AM, Krawczak M, Cooper DN: Human growth hormone 1 (GH1) gene expression: complex haplotype-dependent influence of polymorphic variation in the proximal promoter and locus control region. Hum Mutat 2003;21: 408-423.

-10 Ayling RM, Ross R, Towner P, Von Laue S, Finidori J, Moutoussamy S, Buchanan CR, Clayton PE, Norman MR: A dominant-negative mutation of the growth hormone receptor causes familial short stature. Nat Genet 1997;16:13-14.
11 Woods KA, Fraser NC, Postel-Vinay MC, Savage MO, Clark AJ: A homozygous splice site mutation affecting the intracellular domain of the growth hormone $(\mathrm{GH})$ receptor resulting in Laron syndrome with elevated GH-binding protein. J Clin Endocrinol Metab 1996;81:1686-1690.

12 Iida K, Takahashi Y, Kaji H, Nose O, Okimura $\mathrm{Y}$, Abe $\mathrm{H}$, Chihara $\mathrm{K}$ : Growth hormone (GH) insensitivity syndrome with high serum GH-binding protein levels caused by a heterozygous splice site mutation of the $\mathrm{GH}$ receptor gene producing a lack of intracellular domain. J Clin Endocrinol Metab 1998; 83:531-537.

13 Kofoed EM, Hwa V, Little B, Woods KA, Buckway CK, Tsubaki J, Pratt KL, Bezrodnik L, Jasper H, Tepper A, Heinrich JJ, Rosenfeld RG: Growth hormone insensitivity associated with a STAT5b mutation. N Engl J Med 2003;349:1139-1147.

14 Hwa V, Little B, Adiyaman P, Kofoed EM, Pratt KL, Ocal G, Berberoglu M, Rosenfeld RG: Severe growth hormone insensitivity resulting from total absence of signal transducer and activator of transcription 5b. J Clin Endocrinol Metab 2005;90:42604266.

15 Fang P, Kofoed EM, Little BM, Wang X, Ross RJM, Frank SJ, Hwa V, Rosenfeld RG: A mutant signal transducer and activator of transcription 5b, associated with growth hormone insensitivity and insulin-like growth factor-I deficiency, cannot function as a signal transducer or transcription factor. J Clin Endocrinol Metab 2006;91:1526-1534.

16 Marino R, Ciaccio M, Bernasconi A, Rossi J, Oleastro M, Omani A, Zelasko M, Rivarola MA, Belgorosky A: Identification of a novel nonsense mutation in the STAT5b gene associated with growth hormone insensitivity. Horm Res 2005;64(suppl 1):44.

17 Vidarsdottir S, Walenkamp MJ, Pereira AM, Karperien M, Van Doorn J, van Duyvenvoorde $\mathrm{HA}$, White S, Breuning $\mathrm{MH}$, Roelfsema F, Kruithof MF, van Dissel J, Janssen R, Wit JM, Romijn JA: Clinical and biochemical characteristics of a male patient with a novel homozygous STAT5b mutation. J Clin Endocrinol Metab 2006;E Pub:Jun20.

18 Hwa V, Camacho-Hubner C, Little B, David A, Metherell L, Savage M, Rosenfeld RG: Growth hormone insensitivity and severe short stature in siblings due to a novel splice mutation in exon 13 of the STAT5b gen (Abstract). The Endocrine Society's 88th Annual Meeting 2006, 2006;P1-839:379.

19 Janssen R, van Wengen A, Hoeve MA, ten Dam $M$, van der Burg M, van Dongen J, van de Vosse E, van Tol M, Bredius R, Ottenhoff TH, Weemaes C, van Dissel JT, Lankester A: The same I $\mathrm{B} \alpha$ mutation in two related individuals leads to completely different clinical syndromes. J Exp Med 2004;200:559568.
20 Walenkamp MJE, Lankester A, Oostdijk W, Wit JM: Partial growth hormone insensensitivity and immunodeficiency caused by a disturbance in the NF- $\mathrm{KB}$ signaling pathway. Horm Res 2004;62(suppl 2):103.

$\checkmark 21$ Woods KA, Camacho-Hubner C, Savage MO, Clark AJ: Intrauterine growth retardation and postnatal growth failure associated with deletion of the insulin-like growth factor I gene. N Engl J Med 1996;335:13631367.

22 Bonapace G, Concolino D, Formicola S, Strisciuglio P: A novel mutation in a patient with insulin-like growth factor 1 (IGF1) deficiency. J Med Genet 2003;40:913-917.

23 Walenkamp MJ, Karperien M, Pereira AM, Hilhorst-Hofstee Y, Van Doorn J, Chen JW, Mohan S, Denley A, Forbes B, van Duyvenvoorde HA, van Thiel SW, Sluimers CA, Bax JJ, de Laat JA, Breuning MB, Romijn JA, Wit JM: Homozygous and heterozygous expression of a novel insulin-like growth factor-I mutation. J Clin Endocrinol Metab 2005;90: 2855-2864.

24 Netchine I, Azzi S, Houang M, Seurin D, Daubas C, Ricort J, Legay C, Perin L, Heirich R, Godeau F, Le Bouc Y: Partial IGF-I deficiency demonstrates the critical role of IGF-I in growth and brain development. Horm Res 2006;65(suppl 4):29.

25 Domene HM, Bengolea SV, Martinez AS, Ropelato MG, Pennisi P, Scaglia P, Heinrich JJ, Jasper HG: Deficiency of the circulating insulin-like growth factor system associated with inactivation of the acid-labile subunit gene. N Engl J Med 2004;350:570-577.

26 Hwa V, Haeusler G, Pratt KL, Little BM, Frisch H, Koller D, Rosenfeld RG: Total absence of functional acid labile subunit, resulting in severe insulin-like growth factor deficiency and moderate growth failure. J Clin Endocrinol Metab 2006;91:1826-1831.

27 Okubo Y, Siddle K, Firth H, O’Rahilly S, Wilson LC, Willatt L, Fukushima T, Takahashi SI, Petry CJ, Saukkonen T, Stanhope R, Dunger DB: Cell proliferation activities on skin fibroblasts from a short child with absence of one copy of the type 1 insulin-like growth factor receptor (IGF1R) gene and a tall child with three copies of the IGF1R gene. J Clin Endocrinol Metab 2003;88: 5981-5988.

28 Abuzzahab MJ, Schneider A, Goddard A, Grigorescu F, Lautier C, Keller E, Kiess W, Klammt J, Kratzsch J, Osgood D, Pfaffle R, Raile K, Seidel B, Smith RJ, Chernausek SD: IGF-I receptor mutations resulting in intrauterine and postnatal growth retardation. $\mathrm{N}$ Engl J Med 2003;349:2211-2222. 
-29 Kawashima Y, Kanzaki S, Yang F, Kinoshita T, Hanaki K, Nagaishi Ji, Ohtsuka Y, Hisatome I, Ninomoya H, Nanba E, Fukushima T, Takahashi SI: Mutation at cleavage site of insulin-like growth factor receptor in a short-stature child born with intrauterine growth retardation. J Clin Endocrinol Metab 2005;90:4679-4687.

>30 Walenkamp MJ, Van der Kamp HJ, Pereira AM, Kant SG, van Duyvenvoorde HA, Kruithof MF, Breuning MH, Romijn JA, Karperien M, Wit JM: A variable degree of intrauterine and postnatal growth retardation in a family with a missense mutation in the IGF-I receptor. J Clin Endocrinol Metab 2006;91:3062-3070.
31 Tiulpakov A, Rubtsov P, Sverdlova P, Peterkova V, LeRoith D: A familial case of preand postnatal growth failure associated with a novel heterozygous missense mutation affecting the N-terminal fibronectin type III domain of IGF-IR. Horm Res 2005;64(suppl1):32.

32 Kawashima Y, Yang F, Miura M, Kinoshita T, Nagaishi JI, Hanaki K, Kanzaki S: A family with short stature born intrauterine growth retardation bearing a new missense mutation at $\alpha$ subunit of IGF-I receptor (R431L) (Abstract). The Endocrine Society's 88th Annual Meeting 2006, 2006;P2-117:426.

33 Bellus GA, Spector EB, Speiser PW, Weaver CA, Garber AT, Bryke CR, Israel J, Rosengren SS, Webster MK, Donoghue DJ, Francomano CA: Distinct missense mutations of the FGFR3 lys650 codon modulate receptor kinase activation and the severity of the skeletal dysplasia phenotype. Am J Hum Genet 2000;67:1411-1421.
34 Schiller S, Spranger S, Schechinger B, Fukami M, Merker S, Drop SL, Troger J, Knoblauch H, Kunze J, Seidel J, Rappold GA: Phenotypic variation and genetic heterogeneity in Leri-Weill syndrome. Eur J Hum Genet 2000;8:54-62.

$>35$ Richter-Unruh A, Knauer-Fischer S, Kaspers S, Albrecht B, Gillessen-Kaesbach G, Hauffa BP: Short stature in children with an apparently normal male phenotype can be caused by $45, \mathrm{X} / 46, \mathrm{XY}$ mosaicism and is susceptible to growth hormone treatment. Eur J Pediatr 2004;163:251-256. 